\title{
MORE THAN FRIENDS: THE IMPACT OF SOCIAL MEDIA ON WORD OF MOUTH, BRAND LOYALTY AND PURCHASE INTENTIONS FOR INTERNATIONAL HOTELS
}

\author{
Wen-Jung Chang ${ }^{1 *}$, Jerome M. Katrichis ${ }^{2}$
}

${ }^{1 *}$ Hungkuo Delin University of Technology, Taiwan; ${ }^{2}$ University of Hartford, USA. Email: ${ }^{1 *}$ rickrong@gmail.com, ${ }^{2}$ katrichis@ $@$ hartford.edu

\author{
Article History: Received on $30^{\text {th }}$ April 2020, Revised on $29^{\text {th }}$ May 2020, Published on $14^{\text {th }}$ June 2020
}

\begin{abstract}
Purpose of the study: Increases in global travel have led to the internationalization of the hospitality industry. Though a number of applications of social media have been examined in the hospitality industry, few of them integrate key dimensions of fan pages into a measurement model in the same time, including interactivity (INT), engagement (ENG), trust (TRT), friendship (FRP), word-of-mouth (WOM) and purchase intention (PI).
\end{abstract}

Methodology: Based on 408 valid fans from Facebook fan pages of 24 International hotels in Taiwan, the empirical results show that ENG, FRP, TRT, and WOM all act as partial mediators in their impact on post-purchase behaviors. Based on Taiwanese International hotels, this study attempts to explore why these owners want more than just a friend.

Main findings: The empirical results show that ENG, FRP, TRT, and WOM all act as partial mediators in their impact on post-purchase behaviors. The study demonstrates the mechanisms behind utilizing social media to build solid long term potentially profitable relationships with hotel clientele.

Originality/value: We propose and empirically investigate an integrated theoretical framework to more fully capture and describe the consumer's behavior in the brand community. Our model of the social media process is informed by an "S-O-R" view from consumer behavior, where INT and ENG help create the situation which acts as a stimulus for FRP and TRT which in turn influence BL, WOM, and further PIs. Here, we see the pull force (website INT) as an influence on the brand-consumer relationship (i.e., FRP) through a push force (fan's ENG). Together and along with the brand content they combine to create the consumer stimulus.

Keywords: Social Media, Taiwan Hotels, Hospitality Industry, Brand Loyalty, Purchase Intentions.

\section{INTRODUCTION}

The internet offers unlimited capabilities and possibilities. It allows people to accomplish more than ever before and in less time. Managers of companies today need to strengthen the linkage they have with their consumers so as to chase the huge commercial opportunities following the consecutive stages of their friends, their fans, and their followers. In the context of social marketing (e.g., Facebook), Jahn and Kunz (2012, p.345) argue that social media offer users a variety of online services to communicate with others which results in a completely new communication style. The reason why the Internet is more powerful than traditional media is because the former can do far more interactive activities than the latter (Kim, Spielmann, \& McMillan, 2012; Stewart \& Pavlou, 2002). Facebook was originally designed for empowering people to communicate and interact with friends, but people now increasingly use it to acquire the latest information about brands, consume their services and products, and engage with brands (Verhoef \& Lemon, 2013). In short, Facebook is a mine of consumer information and a revolutionary means of spreading information ( $\mathrm{Hsu}, 2012)$.

One of the main marketing advantages of Facebook is the possibility to create fan pages that new users can join and become fans of. Over time, these fan pages became popular among fans of the companies (Trusov, Bucklin, \& Pauwels, 2009). To some degree, fan pages can be seen as an extension of the consumer-brand relationship by transferring traditional physical distribution to virtual distribution. In the context of social media, friendship can be seen as a means of building a long-term relationship between buyers and sellers (Chung, Liao, \& Chang, 2018b). Practically speaking, nobody wants a long-term relationship with a partner that cannot be trusted (Damtew \& Pagidimarri, 2013). On the other hand, the relationship between brand and consumer can be regarded as a people-to-people relationship. Once a consumer can make friends with others in this community, they will become more honest, loyal, and trusting of each other (Bell, 1981; Rawlins, 1992).

With increased national incomes, the rise of leisure ideology, and the popularization of the global village, foreign/domestic tourism has become a part of people's lives (Chang \& Katrichis, 2016, p. 791). Hospitality as a subsection of tourism is a fundamental part of the domestic and inbound leisure market (Benea, 2014). Those experienced people influenced by the Internet (e.g., advertisement), make it more critical to the hotel sector to manage the relationship with them and make them truly satisfied (Padilla-Meléndez \& Garrido-Moreno, 2014, p. 1; Sigala, 2005, p. 391-392). A number of applications of social media have been examined in the hospitality industry, for example, engagement (ENG) (e.g., Hashim \& Fadhil, 2017), online travel agency (e.g., Stangl, Inversini, \& Schegg, 2016), recruitment (e.g., Ladkin \& Buhalis, 2016), customer relationship management (e.g., Rosman \& Stuhura, 2013), continuance usage information sharing (e.g., Hur, Kim, Karatepe, \& Lee, 2017), knowledge management (e.g., Sigala \& 
Chalkiti, 2015), marketing positioning and effectiveness (e.g., Neirotti, Raguseo, \& Paolucci, 2016) and assessment/performance (e.g., Kim, Lim, Baek, \& Kim, 2015b).

The increase in the global travel market and environmental trends has led to the internationalization of the hospitality industry (Sufi, 2008). According to the annual operation report released by the Tourism Bureau, Taiwan in 2015, there are 71 International hotels in Taiwan, which collectively generate 49.66 billion dollars in yearly operating revenue. Most importantly, the hospitality industry is more customer-oriented (Aswani \& Gugloth, 2017). Since social media is so available to anyone with an internet connection, it should be a platform that can be recommended to the hospitality industry to increase their brand awareness and facilitate direct feedback from their customers (Lim, 2010). Facebook fan pages are widely used by many industries to communicate with their customers, such as airline, fashion, tea/alcoholic drinks, consumer electronics and restaurant and hotels, public sectors and nonprofit organizations, etc. However, recent studies rarely focus on the relationships among the many dimensions of fan pages including interactivity (INT), engagement (ENG), trust (TRT), friendship (FRP), and a number of post-purchase behaviors.

Based on Taiwanese International hotels, therefore, this study attempts to explore why these owners want more than just a friend. We propose and empirically investigate an integrated theoretical framework to more fully capture and describe the consumer's behavior in the brand community. One contribution of this study is the application of the concept of "SO-R" ${ }^{\prime 1}$ into this model. Belk (1975) proposed that situational influences have a sizeable impact on consumer behavior. Our conceptual model views the pull force (i.e., website INT) as an influence on the brand-consumer relationship (i.e., $F R P$ ) through a push force (i.e., fan's $E N G$ ). Together and along with the brand content they combine to create the consumer stimulus. Second, research on FRP related to social media/brand community has been rarely discussed. The second contribution of this study is to empirically explore the importance of FRP between pull/push driven forces from a virtual community and an individual's resulting perception, such as TRT. Of course, we will also examine the relationships among brand loyalty (BL), word-of-mouth (WOM), and purchase intention (PI). We discuss the results of our empirical examination, provide managerial implications, and make suggestions for further study.

\section{LITERATURE REVIEW AND HYPOTHESES DEVELOPMENT}

\section{Interactivity (INT)}

INT can play an essential role in web-based and network-oriented environments (Song \& Zinkhan, 2008). Blattberg and Deighton (1991)) defined INT as the facility for a person and an organization to communicate directly with each other regardless of distance or time. Steuer (1992, p. 84) suggested that INT is "the extent to which users can participate in modifying the format and content of a mediated environment in real-time.INT in online brand communities can improve the quality of communication (Lowry, Romano, Jenkins, \& Guthrie, 2009). Basically, INT refers to a multi-dimensional construct. For example, some scholars propose that INT is composed of two subscale - machine interaction and interpersonal interaction (e.g., Hoffman \& Novak, 1996), the sense of system efficacy and perceived interactivity (e.g., Newhagen, Cordes, \& Levy, 1995) and interpersonal INT and machine INT. (e.g., Keng \& Ting, 2009; Severin \& Tankard, 2000), internal-based efficacy, and externally based system efficacy (e.g., Wu, 1999). Others hold different points of view, for example, Heeter (1989) conceptualizes INT as a six-dimensional construct and Wu (2000) proposes INT composed of three dimensions. Here we take a moderate view consistent with Song and Zinkhan (2008) and conceptualize INT as a three-dimension construct composed of communication (COMM), control (CONT), and responsiveness (RESP).

\section{Engagement (ENG)}

The concept of ENG has been previously examined in a variety of academic disciplines including social psychology, political science, educational psychology, and organizational behavior (Hollebeek, 2010). Brand communities entail a higher level of customer ENG with brands; customers are connected parties who collaborate to add value to the brand experience (Brodie, Hollebeek, Juric, \& Ilic, 2011; Hollebeek, 2011). At present, the terms "ENG", "involvement" and "participation" share some similarities (e.g., Calder \& Malthouse, 2008; Mollen \& Wilson, 2010; INVOLVE 2012). Brodie et al. (2011) refer to ENG as a highly context-dependent psychological state, characterized by a specific intensity level that plays a central role in the process of relational exchange. Our view is consistent with that used in the context of fan pages, where Jahn and Kunz (2012) argue that ENG is referred to as interactive and integrative participation in the fan-page community. This would be distinguished from solely the usage intensity of a member. In the service research community, other scholars regard ENG as a consumer's involvement (Brodie et al., 2011; Van Doorn et al., 2010).

\section{Friendship (FRP)}

DiMaggio and Louch (1998) argue that FRP has often existed between consumers and firm representatives before a single transaction ever happens. Online FRP refers to the existence of FRP between online users. FRP is a bilateral exchange (Patterson, Bettini, \& Nussbaum, 1993). In other words, FRP can be confirmed when individuals accept others as friends and perceive that others accept them as friends. In the context of social media, FRP is an interpersonal concept

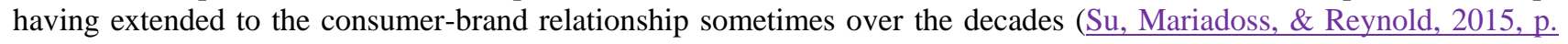

\footnotetext{
${ }^{1}$ The concept of "stimulus-organism-response" (S-O-R) is developed by Belk (1975) 
78). As to the dimensions of FRP, Price, and Arnould (1999) and Su et al. (2015) suggest that FRP is composed of selfdisclosure and reciprocity. This is consistent with our approach. Basow (1992) refers to FRP as a relationship and attitude with intimacy and care, including mutual TRT, reciprocity, loyalty, and inclusion. Recently, some authors refer to FRP as a single-dimensional variable, intimacy (e.g., Butcher, Sparks, \& O'Callaghan, 2001; Han, Kwortnik, \& Wang, 2008).

\section{Trust (TRT)}

TRT is an important factor in many interactions involving uncertainty and dependency. The degree of uncertainty, dependency, and risk is higher in the online world than the offline world (Du Preez, 2009). TRT has been defined as the willingness to rely on an exchange partner in whom one has confidence (Morgan \& Hunt, 2004; Afsar, Ur Rehman, Qureshi, \& Shahjehan, 2010). As to the dimensions, confidence and reliability were shown as essential antecedents of TRT (Matos \& Rossi, 2008). TRT could be divided into cognitive and affective components (e.g., McAllister, 1995; Riegelsberger, Sasse, \& McCarthy, 2003; Chhetri, 2014), or reliability and intentionality (e.g., Delgado, Munuera, \& Yague, 2003). Some authors claim that TRT is composed of benevolence and credibility (Ganesan, 1994; Doney \& Cannon, 1997; Ganguly, Dash, Cyr, \& Head, 2010) or credibility, integrity, and benevolence (e.g., Le Roux, Chandon, \& Strazzieri, 1997). On the contrary, Selnes (1998) argues that TRT can be seen as a one-dimensional construct and directly accessible to respondents.

\section{Brand loyalty (BL)}

Loyalty is the indicator of the success of marketing performance (Afif, Sutiksno, Hardiyanto, \& Shiratina, 2015). Jacoby and Olson (1978)) define BL as a nonrandom behavioral reaction and a long-standing buying behavior. A high level of BL could lower many aspects of cost spent by the organization (Hanzaee \& Andervazh, 2012). As to the dimensions, most scholars claim that BL is a bi-dimensional construct composed of the attitudinal and the behavioral (e.g., Jacoby \& Chestnut, 1978; Dick \& Basu, 1994; Donio, Massari, \& Passiante, 2006; Worthington, Russell-Bennett, \& Hartel, 2009), whereas Jahn and Kunz (2012) identify BL into brand commitment, WOM and repurchase intention.

\section{Purchase intention (PI)}

PI can be explained as the likelihood of the consumer to intend to purchase the product (Dodd \& Supa, 2011). PI has been broadly used as a focal construct to indicate consumers' buying behavior in market research (Yang \& Mao, 2014). PI is the preference of consumers to buy the product or service. In another word, PI has another aspect that the consumer will purchase a product after evaluation (Younus, Rasheed, \& Zia, 2015). Bagozzi and Burnkrant (1979)) defined PI as a personal behavioral tendency to a particular product, while PI is also defined as the possibility the consumer will purchase the products (Danieli, 2016). Shen, Chi, and Chen (2007)) suggested that PI could be measured by the intention to purchase the products advertised or consumption in the stores and even the efforts to search for the products.

\section{Word-of-mouth (WOM)}

WOM is defined as any positive or negative statement made by customers' experiences about a product or company, which is made available to a mass of people and institutions using the Internet (Hennig-Thurau, Gwinner, Walsh, \& Gremler, 2004). According to Harrison-Walker (2001), when products or services are difficult to evaluate, customers prefer to adopt e-WOM as the standard experience. In marketing literature, researchers have reported that WOM plays an important role in the product choice process and in the selection of service providers (Gilly, Graham, Wolfinbarger, \& Yale, 1998). Jason, Georgiana, and Dongwoo (2010)) refer to WOM as the consumers' interpersonal communication about their personal assessments and experiences regarding encountering a company or product.

\section{Hypotheses development}

INT, ENG, and FRP: Brodie et al. (2011) argued that ENG was the relationship and the process characterizing dynamic interaction and was resulted from INT. In the context of online brand communities, feelings of warmth and closeness with other members motivate more frequent interaction and communication (Zhao, Sullivan, \& Mellenius, 2014), which facilitate the formation of embedded relationships, such as FRPs among members (Grayson, 2007; Montgomery, 1998). Therefore, we propose some hypotheses as follows:

\section{H1: INT would have a positive impact on FRP.}

\section{H2: INT would have a positive impact on ENG.}

\section{H3: ENG would have a positive impact on FRP.}

FRP, TRT, and BL: TRT is an important item that helps customers become loyal to the brand (Ahmed, Rizwan, Ahmad, \& Haq, 2014). In the context of Starbucks in Taiwan, Chung et al. (2018b) reveal that both FRP and TRT can influence BL, while FRP would also influence TRT. Many studies have strongly supported that TRT could be a predictor of BL (e.g., Avramakis, 2011; Chinomona, 2011; Afif et al., 2015; Zhou et al., 2012). Therefore, this study proposes.

H4: FRP would have a positive impact on $B L$. 
H5: FRP would have a positive impact on TRT.

H6: TRT would have a positive impact on BL.

ENG and TRT: Nadeem et al. (2015) argue Facebook is a trustworthy platform for shopping, but it still needs help from the various websites of e-tailers to attract more engagement from consumers (Nadeem, 2016, p.71). There is empirical evidence among the extant literature that has shown that TRT will directly influence ENG (e.g., Lin, 2010; Hough, Green, \& Plumlee, 2016) whereas few scholars (e.g., Brehm \& Rahn, 1997; West \& Dawson, 2012) have claimed that ENG would significantly influence TRT. Here we propose.

H7: ENG would have a positive impact on TRT.

BL, WOM, and PI: Early studies on WOM have shown that it has an important impact on customer decisions (Allsop et $\underline{a l ., 2007)}$ and helps them to present a good post-purchase awareness. In the study of Facebook fan pages, Chen, Yang, Chang, and Lee (2017) suggest that positive WOM exerts a positive influence on BL. Habib and Aslam (2014) and Malik, Ghafor, and Iqbal (2013) both argued that BL might significantly impact PI. Many scholars have supported that WOM would have an influence on PI (e.g., Basri, Ahmad, Anuar, \& Ismail, 2015; East, Romaniuk, \& Chawdhary, 2017). However, few studies hold the opposite point of view: PI can predict WOM (e.g., Yasin \& Shamim, 2013; Alshevskaya, 2016). Therefore, this study proposes.

H8: BL would have a positive impact on PI.

H9: BL would have a positive impact on WOM.

H10: WOM would have a positive impact on PI.

\section{RESEARCH METHOD}

\section{Research framework}

This study aims to explore the relationships among INT, ENG, TRT, FRP, and post-purchase behaviors (i.e., BL, WOM, and PI). The research framework is shown in Figure 1.

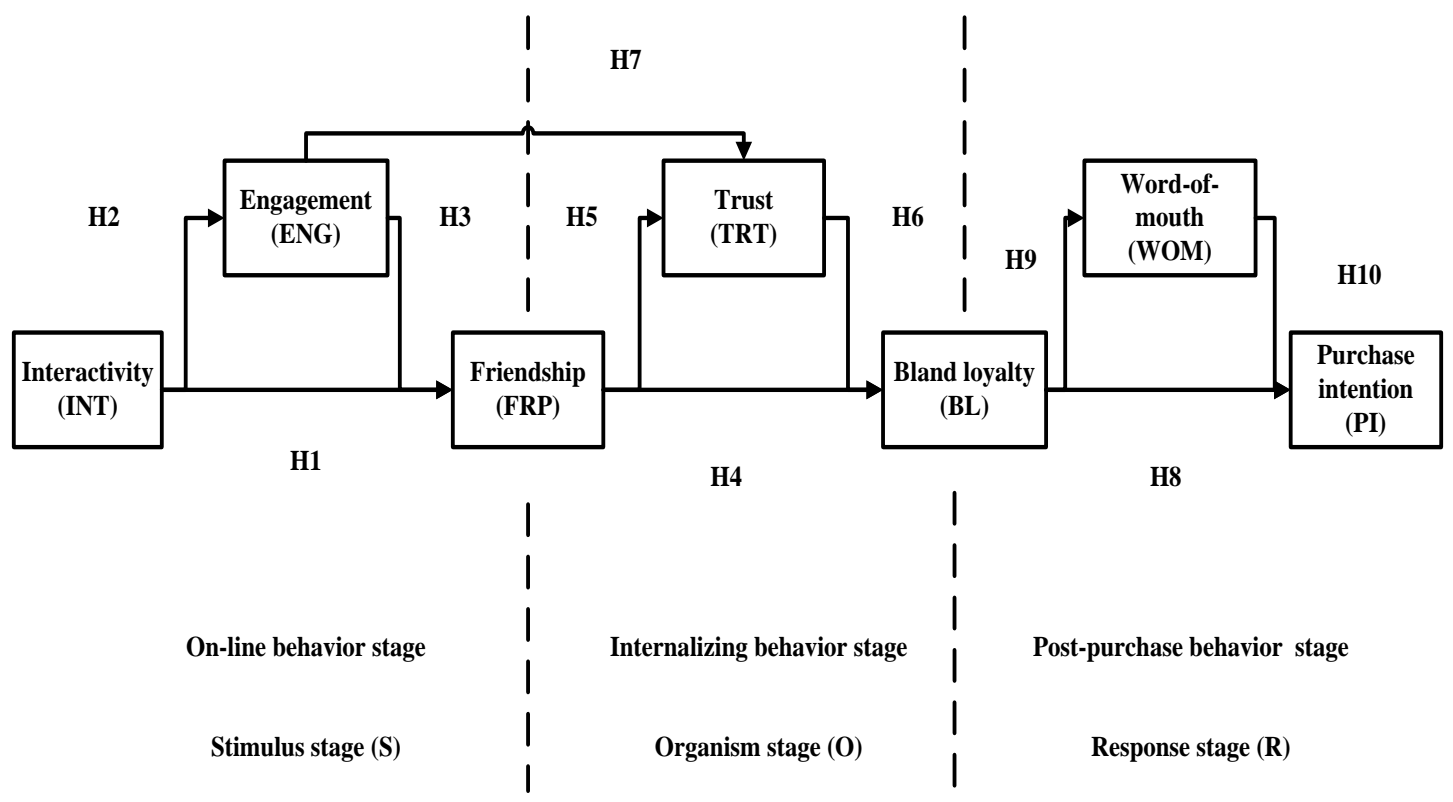

Figure 1: Research Framework

\section{Measurement of variables}

A 7-point Likert scale ( $1=$ strongly disagree, $7=$ strongly agree) was used to measure all constructs. The measures of INT are modified from Liu and Shrum (2002), McMillan and Hwang (2002), and Song and Zinkhan (2008). INT is a threedimension construct with 12 items, including COMM, CONT, and RESP. The measurement of ENG is modified from Jahn and Kunz (2012) and Van Doorn et al. (2010). The construct of ENG is a 4-item construct. The scale of FRP was adopted from Price and Arnould (1999) and friendship here was a single-dimension construct with 7 items. The measurement of TRT is modified from Nadeem et al. (2015). It is a 6-item construct. The measurement of BL is modified from Anderson, Knight, Pookulangara, and Josiam (2014) and Sirohi, McLaughlin, and Wittink(1998). The construct of $\mathrm{BL}$ is a single construct with 4 items. The measurement of PI is modified from Johnson, Herrmann, and Huber (2006), MacKenzie, Lutz, and Belch (1986), Schiffman and Kanuk (2000). The construct of PI is a single construct with 5 items. The measurement of WOM is modified by Chen et al. (2014) and Johnson et al. (2006). The construct of WOM is a single construct with 4 items. 


\section{Data collection and sampling}

In the pre-test stage, we choose those who have visited domestic 3-5-star International hotels in Taiwan during the past 6 months. Then, we randomly sent questionnaires to 40 respondents. Thirty-two valid samples were returned after deleting 3 for incompleteness. To maintain the integrity of the theoretical model, all items from the questionnaire are retained for the formal-test stage. In the formal-test stage, all questionnaires were respectively sent to 24 Taiwanese International hotels ${ }^{2}$, who collectively report more than 12,000 Facebook fans. After a few weeks, 429 questionnaires were collected. After excluding 21 invalid questionnaires, a total of 408 were retained for analysis.

\section{RESULTS AND ANALYSES}

\section{Sample Description}

Based on 408 valid responses, the analysis of demographic variables showed that (1) gender- the ration of male/female is 40.2\%: 59.8\%; (2) Age- about $72 \%$ of the total was no more than 35 years old and $20.8 \%$ ranged from 36 years old to 51 years old; (3) educational background- about $60.5 \%$ of the respondents have their university/college degree; As to the sample-mean analysis, we found that ENG (3.628) was the smallest value among these variables and FRP (3.954) was the second, whereas WOM was the greatest (4.450). There is still considerable room for these managers of international hotels to keep their users staying at the Facebook fan pages. The overall friendship between buyers and sellers seems not so good so far. As to the dimensions of INT, the mean of RESP (4.251) is the smallest, meaning that consumers/users are dissatisfied with the responsiveness from the Facebook fan pages of these international hotels. It reminds these managers of the importance of real-time responses to users' requests.

\section{Reliability and validity}

The Confirmatory factor analysis (CFA) primarily explores the fit between a variable's factor and its measurement items in this questionnaire. The initial model for this study was modified for the purpose of an incomplete model fit by considering the modification indices. After the CFA stage, the values of model fit are GFI= .94; CFI= .99; NNFI= .99; $\mathrm{SRMR}=.028$; RMSEA $=.046$; Normed Chi-square $=1.88$, respectively. It means our measurement model is acceptable. From Table 1, the Cronbach's $\alpha$ value of all these constructs/dimensions ranged from .779 to .923 . This study further verified the convergent validity of our constructs to ensure construct validity. In addition, all the t-values for each construct are significant (t-value ranged from 16.91 to 24.3), which indicates that the convergent validity of this model is acceptable. As to correlation analysis, we found that all the correlations between factors are significant (See Table 2).

Table 1: Reliability analysis

\begin{tabular}{llll}
\hline Variables & Dimensions & items & Cronbach's $\boldsymbol{\alpha}$ \\
\hline \multirow{3}{*}{ INT } & COMM & 2 & .779 (dimension) \\
\cline { 2 - 4 } & CONT & 2 & .779 (dimension) \\
\cline { 2 - 4 } & RESP & 2 & .859 (construct) \\
\hline ENG & -- & 3 & .923 (construct) \\
\hline TRT & -- & 2 & .821 (construct) \\
\hline BL & -- & 2 & .862 (construct) \\
\hline PI & -- & 3 & .907 (construct) \\
\hline WOM & -- & 2 & .850 (construct) \\
\hline FRP & -- & 3 & .896 (construct) \\
\hline
\end{tabular}

Table 2: Correlation analysis

\begin{tabular}{|c|c|c|c|c|c|c|c|c|c|}
\hline & Mean & $\begin{array}{l}\text { Standard } \\
\text { deviation }\end{array}$ & (1) & (2) & (3) & (4) & (5) & (6) & (7) \\
\hline INT (1) & 4.367 & 1.169 & 1 & & & & & & \\
\hline ENG (2) & 3.582 & 1.666 & $.641^{* *}$ & 1 & & & & & \\
\hline TRT (3) & 4.173 & 1.379 & $.647^{* *}$ & $.532^{* *}$ & 1 & & & & \\
\hline BL (4) & 4.474 & 1.422 & $.540^{* *}$ & $.446^{* * *}$ & $.589^{* * *}$ & 1 & & & \\
\hline PI (5) & 4.332 & 1.452 & $.510^{* *}$ & $.454^{* *}$ & $.627^{* *}$ & $.723^{* *}$ & 1 & & \\
\hline WOM (6) & 4.478 & 1.419 & $.545^{* *}$ & $.460^{* * *}$ & $.675^{* * *}$ & $.654^{* *}$ & $.755^{* *}$ & 1 & \\
\hline FRP (7) & 3.954 & 1.492 & $.472^{* * *}$ & $.594^{* * *}$ & $.567^{* * *}$ & $.427^{* * 1}$ & $.460^{* *}$ & $.527^{* *}$ & 1 \\
\hline
\end{tabular}

\section{Model analysis}

From Figure 2, we found that only FRP- $>$ BL $\left(\beta_{42}=.04\right.$, t-value $\left.=.71, \mathrm{P}>.025\right)$ was not significant, while the others were significantly supported, including INT- $>$ ENG $\left(\gamma_{11}=.72\right.$, $\mathrm{t}$-value $\left.=13.96, \mathrm{P}<.001\right)$, INT- $>$ FRP $\left(\gamma_{21}=.15\right.$, t-value $=2.17$, $\mathrm{P}<.025), \mathrm{ENG}->\mathrm{FRP}\left(\beta_{21}=.53, \mathrm{t}\right.$-value $\left.=7.46, \mathrm{P}<.001\right), \mathrm{ENG}->$ TRT $\left(\beta_{31}=.39, \mathrm{t}-\right.$ value $\left.=6.36, \mathrm{P}<.001\right)$, FRP $->$ TRT $\left(\beta_{32}=\right.$ 
$.40, \mathrm{t}-$ value $=6.58, \mathrm{P}<.001)$, TRT $->\mathrm{BL}\left(\beta_{43}=.75, \mathrm{t}-\right.$ value $\left.=10.03, \mathrm{P}<.001\right), \mathrm{BL}->\mathrm{PI}\left(\beta_{64}=.49, \mathrm{t}-\mathrm{value}=6.15, \mathrm{P}<.001\right), \mathrm{BL}-$ $>\operatorname{WOM}\left(\beta_{54}=.84\right.$, t-value $\left.=15.76, \mathrm{P}<.001\right)$ and WOM- $>$ PI $\left(\beta_{65}=.45\right.$, t-value $\left.=5.57, \mathrm{P}<.001\right)$.

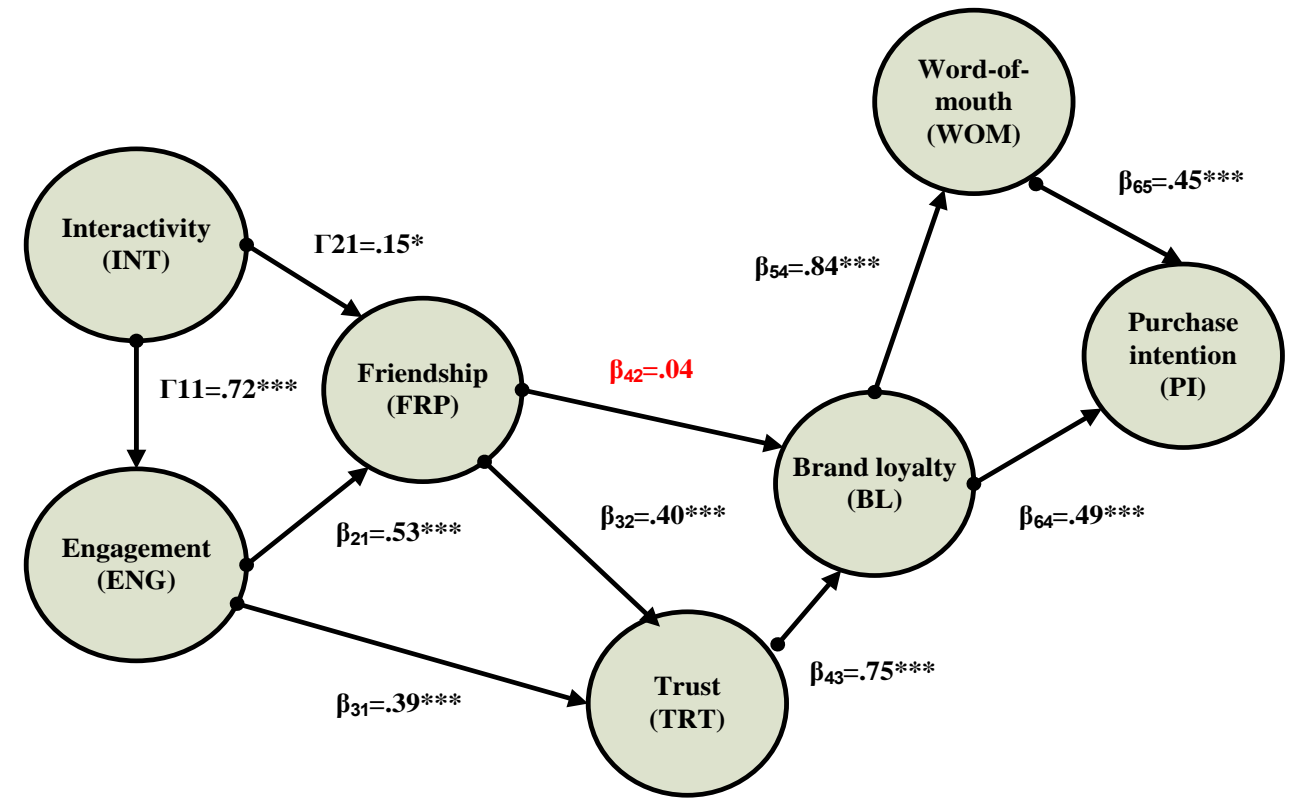

Chi-square $=428.1, \mathrm{df}=125, \mathrm{P}-$ value $=0.00000, \mathrm{RMSEA}=0.077$

$* * * \mathrm{p}<.001, * \mathrm{p}<.025$

Figure 2: Path analysis

\section{DISCUSSIONS, MANAGERIAL IMPLICATIONS}

\section{Discussions}

The empirical findings show that INT may positively influence FRP (i.e., H1 is supported), meaning that the higher level of INT the fans perceived on the fan page, the deeper the FRP (i.e., brand-customer relationship). Next, INT may positively influence ENG (i.e., H2 is supported). This would indicate that the higher the level of INT on the fan page, the more likely fans would be eager to participate in events or activities here. This finding is consistent with Brodie et al. (2011) and Hollebeek (2011). Additionally, ENG may also positively impact FRP (i.e., H3 is supported). It shows that the higher level of ENG the fans experience, the closer FRP between customers and brand will get.

Most importantly, FRP is not as expected to have a positive impact on BL (i.e., H4 is not supported). It means that no matter the more deeply FRP between users and brands is felt, it still cannot change how these fans to show their loyalty to the brand. This finding is not consistent with Chung et al. (2018b) and Zhou, Su, Zhou, and Zhang (2016) stating that when members make more friends in online brand communities, they tend to exchange more values and experiences with them, which motivates their commitment to the brand community. Meanwhile, FRP may have a positive impact on TRT (i.e., H5 is supported). It means that the higher level of FRP in the fan pages, the higher level of fans' loyalty to this brand. This finding is consistent with Chung et al. (2018b). However, past studies have not directly validated the relationship between FRP and TRT. Thus, we can examine their causality through relationship quality, which can be measured by TRT, satisfaction, and loyalty (e.g., Crosby, Evans, \& Cowles, 1990; Kumar, Scheer, \& Steenkamp, 1995; Garbarino \& Johnson, 1999; Price \& Arnould, 1999; Su et al., 2015). Our paper also finds that TRT may have a positive impact on BL (i.e., H6 is supported). It means that a higher level of TRT that fans perceive in the Facebook fan pages, the more apt fans are to be loyal to the brand. These results are consistent with Chinomona (2011), Afif et al. (2015), and Zhou et al. (2012). Based on the results mentioned from H4 to H6, the only way for hotel brands to link FRP to BL is TRT.

As to the post-purchase behavior, we find that BL may positively influence PI (i.e., H7 is supported). It means that a loyal fan in this community will often have a higher PI to the brand product. This finding is consistent with Malik et al. (2013), Habib and Aslam (2014), and Hameed and Kanwal (2018). Besides, BL also has a positive influence on WOM (i.e., H8 is supported). It means that a loyal fan in this community will be more likely to recommend the brand product to others. It is consistent with Basri et al. (2015) and Niyomsart and Khamwon (2016). Finally, WOM is expected to impact PI (i.e., H9 is supported). It means that a fan willing to recommend the brand product will also have a higher intention to purchase in the future. This finding is consistent with Bataineh (2015) and Yusuf (2018). 


\section{Managerial implications}

The findings of this study point to a number of managerial implications. First, based on the theoretical framework (i.e., S-O-R \& pull-push forces). INT and ENG refer to pull force and push force, respectively. Brand manufacturers can use INT to attract/or pull consumers to visit, and then use ENG to help them stay on fan pages to make friends with other members, even be more positively inclined to buy the brand product in the future. Importantly, we confirm the view of Brodie et al. (2011), supporting ERG is coming from INT. Since ENG plays a partial mediator role in INT-FRP relationship, it encourages brand owners to help users/fans to feel deep self-identification to the brand, thereby increasing the probability of developing long-term customer relationships. In a word, in the stage "S" (i.e., stimulus/online behavior stage), the website INT would be the prerequisite factor for the development of FRP in the beginning, while fans' ENG is the determinant factor to the longevity of FRP.

In the "O" stage (i.e., organism/internalizing behavior stage), it seems that TRT is better than FRP to achieve better loyalty to a specific brand. That is TRT is gaining an advantage over FRP in the enhancement of BL. Obviously, nobody expects a long-term relationship with a partner that cannot be trusted (Damtew \& Pagidimarri, 2013). Thus, brand manufacturers must focus on anything affecting TRT in the virtual community, for example, website quality (e.g., Hsu, 2008), responsiveness (e.g., Ridings, Gefen, \& Arinze, 2002), privacy (e.g., Antoniou \& Batten, 2011) and security (e.g., Bojang, 2017), etc.

The last stage in the framework is "R" (response/post-purchase behavior stage), the findings, as expected show that WOM will help a loyal customer to induce a higher possibility of purchase of the brand product in the following days. Thus, brand manufacturers today need to do their best to manage their fan pages well so as to win a fan's heart and the resulting good reputation will ultimately lead that fan and other fans to recommend the brand product as well as increasing the intention to purchase.

This study has several contributions to the literature. As a whole, FRP in the field of social media (i.e., online FRP) has been rarely discussed, especially the hospitality industry. In addition, this study makes an attempt to introduce the "S-OR" mechanism from consumer behavior into this model to further validate these research hypotheses. Finally, this study puts many constructs related to social media marketing into a more comprehensive conceptual model concurrently. From this, the findings can widen the researcher's view of fan pages.

\section{SUGGESTIONS AND FUTURE WORKS}

Variables substitution and addition: To some degree, the fan pages of a company brand can be also seen as a brand. Thus, all brand-related variables can be used in the future, for example, brand image (e.g., Richardson, Dick, \& Jain,1994; Dobni \& Zinkhan 1990), brand knowledge/brand equity (e.g., Barreda, 2014; Park, MacInnis, Priester, Eisingerich, \& Iacobucci, 2010), brand experience/experiential value (e.g., Dovaliene, Masiulyte, \& Piligrimiene, 2015; Brakus, Schmitt, \& Zarantonello, 2009; Chen \& Lin 2015), involvement (e.g., Mandelli, 2008), satisfaction (e.g., Hoffman, Novak, \& Peralta, 1999; Urban, Sultan, \& Qualls, 2000; Jin \& Park, 2006), loyalty (e.g., Kim et al., 2015b), brand attitude/attachment (e.g., Kim, Spiller, \& Hettche, 2015a; Park et al., 2010) and brand love (e.g., Carroll \& Ahuvia, 2006; Vernuccio, Pagani, Barbarossa, \& Pastore, 2015). On the other hand, brand personality has seen heated debate in the field of consumer behavior. Consumers thus can extend their own personality by brand (Ahmad \& Thyagaraj, 2015), such as durable goods (i.e., non-consumables), expensive goods or hedonic products, etc. (e.g., Govers \& Schoormans, 2005; Kumar, Luthra, \& Datta, 2006; Chang, 2014). Thus, future work can focus on brand personality/or consumer personality to see how it impacts relationships within the model.

Comparative analysis: This paper chooses Facebook fan pages of International hotels in Taiwan as our research object. However, there are many industries/brands that have their own fan pages on Facebook, for example, Starbucks, Adidas, Coca-cola, Toyota, McDonalds, 7-11, and so on. Thus, a comparative analysis with a between-industry perspective is necessary. Of course, scholars of great interest in B\&B can make another comparative analysis between B\&B International hotels.

Transformation of variables' attributes: In here, we examine 4 mediating effects (e.g., ENG, FRP, TRT, and WOM), while INT as an exogenous variable. According to the study of Bucy and Tao (2007), INT can be seen as a mediator as well as a moderator. Similarly, ENG (e.g., Greve, 2014; Chung, Chang, \& Liao, 2017), TRT (e.g., Chung et al., 2017; Chung, Liao, \& Chang, 2018a; Triplett \& Loh, 2018), FRP (e.g., Schwartz, Dodge, Pettit, \& Bates, 2000; Glaser, Shelton, \& Bree, 2010) and WOM (e.g., Nghia, Thanh, \& Bao, 2017) have all been used as moderators at some point among extant literature. Thus, the future work can examine changes in their original position.

Different model settings: By contrast, future works can explore different model settings, for example, (1) the moderating effect of ENG on the relationships among INT, TRT, and BL; (2) the moderating effects of BL on the relationships between TRT and FRP, while two driven forces (e.g., INT \&ENG) influence the TRT-FRP relationship. (3) three moderators (e.g., INT, ENG \& FRP) in the relationships among TRT, BL, WOM, and PI.

Other issues: As FRP here is holding the key to the TRT, BL, thereby enhancing the post-purchase constructs (e.g., WOM \& PI), thus, exploring the factors affecting FRP in the future is required. On the other hand, website quality, security, privacy, and responsiveness in the community have attracted lots of attention recently (e.g., Hsu, 2008; Ridings 
et al., 2002; Antoniou \& Batten, 2011; Bojang, 2017). Thus, future work can switch their original position. Thus, new topics in the model are expected.

\section{CONCLUSIONS}

Based on 406 valid fans who have been visited the International hotels in Taiwan, this study aimed to explore the relationships among INT, ENG, FRP, TRT, and post-purchase behavior. The empirical findings indicate that (1) ENG has a partial mediation effect on the INT-FRP relationship; (2) ENG can influence TRT through FRP; (3) TRT also plays a partial mediator role in the relationship between FRP and BL. (4). BL and WOM can influence PI, while BL can also influence WOM. Most importantly, the strength of FRP-BL is not significant among other paths shown in this model, meaning that FRP without any endorsement from TRT is useless to BL. In other words, what owners of International hotels want is nothing but the potential profitability behind a solid and long-term FRP with their customers.

\section{REFERENCES}

1. Afif, N.C., Sutiksno, D.U., Hardiyanto, N., \& Shiratina, A. (2015). Building brand loyalty through increasing brand trust and brand affect. International Journal of Scientific \& Technology Research, 4(11), 336-340.

2. Afsar, B., Ur Rehman, Z., Qureshi, J.A., \& Shahjehan, A. (2010). Determinants of customer loyalty in the banking sector: The case of Pakistan. African Journal of Business Management, 4(6), 1040-1047.

3. Ahmad, A., \& Thyagaraj, K.S. (2015). Understanding the influence of brand personality on consumer behavior. Journal of Advanced Management Science, 3(1), 38-43.https://doi.org/10.12720/joams.3.1.38-43

4. Ahmed, Z., Rizwan, M., Ahmad, M., \& Haq, M. (2014). Effect of brand trust and customer satisfaction on brand loyalty in Bahawalpur. Journal of Sociological Research, 5(1), 306326.https://doi.org/10.5296/jsr.v5i1.6568

5. Allsop, D.T., Bassett, B.R., \& Hoskins, J.A. (2007). Word-of-mouth research: principles and applications. Journal of Advertising Research, 47(4), 398-411.https://doi.org/10.2501/S0021849907070419

6. Alshevskaya, T. (2016). Determinants and impact of the perceived value of an ad on the consumers' perceptions and behavioral responses (Unpublished doctoral dissertation). International Business School of Technology and Management of the Polytechnic Institute of Leiria. Portugal.

7. Anderson, K.C., Knight, D.K., Pookulangara, S., \& Josiam, B. (2014). Influence of hedonic and utilitarian motivations on retailer loyalty and purchase intention: A facebook perspective. Journal of Retailing and Consumer Services, 21(5), 773-779.https://doi.org/10.1016/j.jretconser.2014.05.007

8. Antoniou, G., \& Batten, L. (2011). E-commerce: Protecting purchaser privacy to enforce trust. Electronic Commerce Research, 11(1), 421-456.https://doi.org/10.1007/s10660-011-9083-3

9. Aswani, V., \& Gugloth, S. (2017, October). Social media usage as communication tool by hospitality industry. National Conference on Marketing and Sustainable Development, October 13-14, Rajampet, Andhra Pradesh, India. ISBN 978-1-943295-10-4, pp. 301-309.

10. Avramakis, E. (2011). Relationship management in Swiss finance services: An investigation into relationship and bonding values of highly-involved and confident customers (Unpublished master thesis). Business of Administration, Southern Cross University. Australia.

11. Bagozzi, R.P., \& Burnkrant, R.E. (1979). Attitude organization and attitude-behavior relationship. Journal of Personality and Social Psychology, 37(1), 913-929.https://doi.org/10.1037/0022-3514.37.6.913

12. Barreda, A. (2014). Website interactivity as a branding tool for hotel websites (Unpublished doctoral dissertation). Department of Education in the Rosen College of Hospitality Management at the University of Central Florida Orlando, Florida.

13. Basow, S.A. (1992). Gender stereotypes and roles (3rd ed.). Pacific Grove, CA: Brooks/Cole.

14. Basri, N.A.H., Ahmad, R., Anuar, F.I., \& Ismail, K.A. (2015). Effect of word of mouth communication on consumer purchase decision: Malay upscale restaurant. Procedia-Social and Behavioral Sciences, 222(1), 324331. https://doi.org/10.1016/j.sbspro.2016.05.175

15. Bataineh, Q.A. (2015). The impact of perceived e-WOM on purchase intention: The mediating role of corporate image. International Journal of Marketing Studies, 7(1), 126-137. https://doi.org/10.5539/ijms.v7n1p126

16. Belk, R.W. (1975). Situational variables and consumer behavior. Journal of Consumer Research, 2(3), 157164. https://doi.org/10.1086/208627

17. Bell, R.R. (1981). Worlds of friendship. CA: Sage Publications.

18. Benea, I.A. (2014). Influences of social media on the tourism and hospitality industry (Unpublished bachelor thesis). Modul Vienna University, Vienna.

19. Blattberg, R., \& Deighton, J. (1991). Interactive marketing: Exploiting the age of addressability. Sloan Management Review, 33(1), 5-14.

20. Bojang, I. (2017). Determinants of trust in B2C e-commerce and their relationship with consumer online trust: 
A case of Ekaterinburg, Russian Federation. Journal of Internet Banking and Commerce, 22(s8), 1-59. https://doi.org/10.1063/1.5013938

21. Brakus, J.J., Schmitt, B.H., \& Zarantonello, L. (2009). Brand experience: What is it? How is it measured? Does it affect loyalty? Journal of Marketing, 73(3), 52-68. https://doi.org/10.1509/jmkg.73.3.052

22. Brehm, J., \& Rahn, W. (1997). Individual level evidence for the causes and consequences of social capital. American Journal of Political Science, 41, 888-1023. https://doi.org/10.2307/2111684

23. Brodie, R.J., Hollebeek, L.D., Juric, B., \& Ilic, A. (2011). Customer engagement: Conceptual domain, fundamental propositions \& implications for research. Journal of Service Research, 14(3), 252-271. https://doi.org/10.1177/1094670511411703

24. Bucy, E.P., \& Tao, C.C. (2007). The mediated moderation model of interactivity. Media Psychology, 9(3), 647-672. https://doi.org/10.1080/15213260701283269

25. Butcher, K., Sparks, B., \& O'Callaghan, F. (2001). Evaluative and relational influences on service loyalty. $\begin{array}{lllll}\text { International Journal of Service Industry Management, } & 12(4), \quad 310-327 .\end{array}$ https://doi.org/10.1108/09564230110405253

26. Calder, B.J., \& Malthouse, E.C. (Eds.). (2008). Media engagement and advertising effectiveness. In B.J. Calder (Ed), Kellogg on media and advertising (pp.1-36). NY: Wiley.

27. Carroll, B.A., \& Ahuvia, A.C. (2006). Some antecedents and outcomes of brand love. Marketing Letter, 17, 79-89 https://doi.org/10.1007/s11002-006-4219-2

28. Chang, C.Y. (2014). Visualizing brand personality and personal branding: Case analysis on Starbucks and Nike's brand value co-creation on Instagram (Unpublished master thesis). University of Iowa, USA.

29. Chang, W.J., \& Katrichis, J.M. (2016). A literature review of tourism management (1990-2013): A content analysis perspective. Current Issues in Tourism, 19(8), 791-823. https://doi.org/10.1080/13683500.2016.1167177

30. Chen, G.L., Yang, S.C., Chang, R.M., \& Lee, T.L. (2017, July). The antecedents of brand loyalty building in fan page of Facebook. Proceedings of the 4th Multidisciplinary International Social Networks Conference (MISNC), July 17-19, 2017, Bangkok, Thailand.

31. Chen, H., Papazafeiropoulou, A., Chen, T.K., Duan, Y., \& Liu, H.W. (2014). Exploring the commercial value of social networks. Journal of Enterprise Information Management, 27(5), 576-598. https://doi.org/10.1108/JEIM-05-2013-0019

32. Chen, S.C., \& Lin, C.P. (2015). The impact of customer experience and perceived value on sustainable social relationship in blogs: An empirical study. Technological Forecasting \& Social Change, 96, 40-50. https://doi.org/10.1016/j.techfore.2014.11.011

33. Chhetri, P. (2014). The role of cognitive and affective trust in the relationship between organizational justice and organizational citizenship behavior: A conceptual framework. Business: Theory and Practice, 15(2), 170178. https://doi.org/10.3846/btp.2014.17

34. Chinomona, R. (2011). Non-mediated channel powers and relationship quality: A case of SMES in Zimbabwe channels of distribution (Unpublished $\mathrm{PhD}$ dissertation). National Central University, Taiwan.

35. Chung, Y.C., Chang, W.J., \& Liao, S.H. (2017). "Interactivity and Engagement" which one holds a stake in the relationship between trust and post-purchase behavior in context of Facebook Fan pages? -A case of Starbucks (Chinese), International Journal of Commerce and Strategy, 9(4), 257-278.

36. Chung, Y.C., Liao, S.H., Chang, W.J., (2018a). The moderating effect of trust on the relationships among website interactivity, fan's engagement, loyalty and WOM: A case study of Starbucks Facebook fanpage (Chinese), Annals of Leisure and Recreation Research, 9(2), 1-48.

37. Chung, Y.C., Liao, S.H., \& Chang, W.J. (2018b). Longlive Friendship? Relationships among friendship, trust and brand loyalty: A study of Starbucks. International Journal of Web Based Communities, 14(4), 335-352. https://doi.org/10.1504/IJWBC.2018.096244

38. Crosby, L.A., Evans, K.R., \& Cowles, D. (1990). Relationship quality in services selling: An interpersonal influence perspective. Journal of Marketing, 54(3), 68-81. https://doi.org/10.1177/002224299005400306 https://doi.org/10.2307/1251817

39. Damtew, K., \& Pagidimarri, V. (2013). The role of "trust" in building customer loyalty in insurance sector- A study. IOSR Journal of Business and Management, 14(4), 82-93. https://doi.org/10.9790/487X-1448293

40. 40. Danieli, E. (2016). Social media marketing system aiming at increasing purchase intentions on B2C ecommerce sites (Unpublished master thesis). Linnaeus University, Växjö, Sweden.

41. Delgado, E., Munuera, J.L., \& Yague, M.J. (2003). Development and validation of a brand trust scale. International Journal of Market Research, 45(1), 35-54. https://doi.org/10.1177/147078530304500103

42. Dick, A., \& Basu, K. (1994). Customer loyalty: Towards an integrated framework. Journal of the Academy of Marketing Science, 22(2), 99-113. https://doi.org/10.1177/0092070394222001 
43. DiMaggio, P., \& Louch, H. (1998). Socially embedded consumer transactions: For what kinds of purchases do people most often use networks?' American Sociological Review, 63(5), 619-637. https://doi.org/10.2307/2657331

44. Dobni, D., \& Zinkhan, G.M. (1990). In search of brand image: A foundation analysis. Advances in Consumer Research, 17(1), 110-119.

45. Dodd, M.D., \& Supa, D.W. (2011). Understanding the effect of corporate social responsibility on consumer purchase intention. Public Relations Journal, 5(3), 1-19.

46. Doney, P.M., \& Cannon, J.P. (1997). An examination of the nature of trust in buyer-seller relationship. Journal of Marketing, 61(2), 35-51.

47. Donio, J., Massari, P., \& Passiante, G. (2006). Customer satisfaction and loyalty in a digital environment: An empirical test. Journal of Consumer Marketing, 23(7), 445-457. https://doi.org/10.1108/07363760610712993

48. Dovaliene, A., Masiulyte, A., \& Piligrimiene, Z. (2015). The relations between customer engagement, perceived value and satisfaction: the case of mobile applications. Procedia-Social and Behavioral Sciences, 213, 659-664. https://doi.org/10.1016/j.sbspro.2015.11.469

49. Du Preez, M. (2009). Trust and new technologies: Marketing and management on the internet and mobile media. Online Information Review, 33(6), 1208-1209. https://doi.org/10.1108/14684520911011151

50. East, R., Romaniuk, J., \& Chawdhary, R. (2017). The impact of word of mouth on intention to purchase currently used and other brands. International Journal of Market Research, 59(3), 321-334. https://doi.org/10.2501/IJMR-2017-026

51. Ganesan, S. (1994). Determinants of long-term orientation in buyer-seller relationship. Journal of Marketing, 58(2), 1-19.

52. Ganguly, B., Dash, S.B., Cyr, D., \& Head, M. (2010). The effects of website design on purchase intention in online shopping: The mediating role of trust and the moderating role of culture. International Journal of Electronic Business, 8(4), 302-330. https://doi.org/10.1504/IJEB.2010.035289

53. Garbarino, E., \& Johnson, M.S. (1999). The different roles of satisfaction, trust, and commitment in customer relationships. Journal of Marketing, 63(2), 70-87.

54. Gilly, M.C., Graham, J.L., Wolfinbarger, M.F., \& Yale, L.J. (1998). A dyadic study of international information search. Journal of the Academy of Market Science, 26(2), 83-100. https://doi.org/10.1177/0092070398262001

55. Glaser, B., Shelton, K., \& Bree, M. (2010). The moderating role of close friends in the relationship between conduct problems and adolescent substance use. Journal of Adolescent Health, 47(1), 35-42. https://doi.org/10.1016/j.jadohealth.2009.12.022

56. Govers, P.C.M., \& Schoormans, J.P.L. (2005). Product personality and its influence on consumer preference. Journal of Consumer Marketing, 22(4), 189-197. https://doi.org/10.1108/07363760510605308

57. Grayson, K. (2007). Friendship versus business in marketing relationships. Journal of Marketing, $71(4), 121$ 139. https://doi.org/10.1509/jmkg.71.4.121

58. Greve, G. (2014). The moderating effect of customer engagement on the brand image-brand loyalty relationship. Procedia- Social and Behavioral Sciences, 148, 203-210. https://doi.org/10.1016/j.sbspro.2014.07.035

59. Habib, S., \& Aslam, S. (2014). Influence of brand loyalty on consumer repurchase intentions of Coca-Cola. European Journal of Business and Management, 6(14), 168-174.

60. Hameed, S., \& Kanwal, M. (2018). Effect of brand loyalty on purchase intention in cosmetics industry. Research in Business and Management, 5(1), 25-35. https://doi.org/10.5296/rbm.v5i1.12704

61. Han, X.Y., Kwortnik, R.J., \& Wang, C.X. (2008). Service loyalty: An integrative model and examination across service contexts. Journal of Service Research, 11(1), 22-24. https://doi.org/10.1177/1094670508319094

62. Hanzaee, K.H., \& Andervazh, L. (2012). The influence of brand loyalty on cosmetics purchase intention of Iranian female consumers. Journal of Basic and Applied Scientific Research, 2(5), 5389-5398.

63. Harrison-Walker, L.J. (2001). The measurement of word-of-mouth communication and an investigation of service quality and customer commitment as potential antecedents. Journal of Service Research, 4(1), 60-75. https://doi.org/10.1177/109467050141006

64. Hashim, K.F., \& Fadhil, N.A. (2017). Engaging with customer using social media platform: A case study of Malaysia hotels. Procedia Computer Science, 124, 4-11. https://doi.org/10.1016/j.procs.2017.12.123

65. Hennig-Thurau, T., Gwinner, K.P., Walsh, G., \& Gremler, D.D. (2004). Electronic word-of-mouth via consumer-opinion platforms: What motivates consumers to articulate themselves on the Internet? Journal of interactive marketing, 18(1), 38-52. https://doi.org/10.1002/dir.10073

66. Heeter, C. (1989). Implications of interactivity for communication research. In J. Salvaggio \& J. Bryant (Eds), Media use in the information age: Emerging patterns of adoption and consumer use (pp. 217-235). Hillsdale, 
NJ: Erlbaum Associates.

67. Hoffman, D.L., \& Novak, T.P. (1996). Marketing in hypermedia computer-mediated environments: Conceptual foundations. Journal of Marketing, 60(3), 50-68.

68. Hoffman, D.L., Novak, T.P., \& Peralta, M. (1999). Building customer trust online. Communications of the ACM, 42(4), 80-85. https://doi.org/10.1145/299157.299175

69. Hollebeek, L.D. (2010, November). The customer engagement/value interface: Conceptual model \& research implication. ANZMAC Annual Conference 2010, College of Business and Economics University of Canterbury Christchurch New Zealand.

70. Hollebeek, L. (2011). Exploring customer brand engagement: Definition and themes. Journal of Strategic Marketing, 19(7), 555-573. https://doi.org/10.1080/0965254X.2011.599493

71. Hough, C., Green, K., \& Plumlee, G. (2016). Impact of ethics environment and organizational trust on employee engagement. Journal of Legal, Ethical and Regulatory Issues, 18(3), 45-67.

72. Hsu, C.J. (2008). Dominant factors for online trust. International Conference on Cyberworlds 2008, $165-172$. https://doi.org/10.1109/CW.2008.21

73. Hsu, Y.L. (2012). Facebook as international e-marketing strategy of Taiwan hotels. International Journal of Hospitality Management, 31, 972-980. https://doi.org/10.1016/j.ijhm.2011.11.005

74. Hur, K.S., Kim, T.G., Karatepe, O.M., \& Lee, G.H. (2017). An exploration of the factors influencing social media continuance usage and information sharing intentions among Korean travelers. Tourism Management, 63(1), 170-178. https://doi.org/10.1016/j.tourman.2017.06.013

75. INVOLVE (2012), Briefing notes for researchers: Public involvement in NHGS, public health and social care. Eastleigh, Hampshire, UK.

76. Jacoby, J., \& Chestnut, R.W. (1978). Brand loyalty measurement and management. New York: Wiley

77. Jacoby, J., \& Olson, J.C. (1978). An attitude model of brand loyalty: Conceptual underpinnings instrumentation research. In J. Jacoby \& R.W. Chestnut (Eds.). Brand loyalty: Measurement and management (pp. 1-32). New York: John Wiley and Sons.

78. Jahn, B., \& Kunz, W. (2012). How to transform consumers into fans of your brand. Journal of Service Management, 23(3), 344-361. https://doi.org/10.1108/09564231211248444

79. Jason, Q.Z., Georgiana, C., \& Dongwoo, S. (2010). When does electronic word-of-mouth matter? A study of consumer product reviews. Journal of Business Research, 63, 1336-1341. https://doi.org/10.1016/j.jbusres.2009.12.011

80. Jin, B., \& Park, J.Y. (2006). The moderating effect of online purchase experience on the evaluation of online store attributes and the subsequent impact on market response outcomes. In C. Pechmann \& L.L. Price (Eds.). Advances in consumer research (Vol. 33, pp. 203-211). Valdosta: Association for Consumer Research

81. Johnson, M.D., Herrmann, A., \& Huber, F. (2006). The evolution of loyalty intentions. Journal of Marketing, 70(2), 122-132. https://doi.org/10.1509/jmkg.70.2.122

82. Keng, C.J., \& Ting, H.Y. (2009). The acceptance of blogs: Using a customer experiential value perspective. Internet Research, 19, 479-495. https://doi.org/10.1108/10662240910998850

83. Kim, D.H., Spiller, L., \& Hettche, M. (2015a). Analyzing media types and content orientations in Facebook for global brands. Journal of Research in Interactive Marketing, 9, 4-30. https://doi.org/10.1108/JRIM-05-20140023

84. 84. Kim, J., Spielmann, N., \& McMillan, S.J. (2012). Experience effects on interactivity: Functions, processes, and perceptions. Journal of Business Research, 65, 1543-1550. https://doi.org/10.1016/j.jbusres.2011.02.038

85. Kim, S., Lim, C.M., Baek, T.H., \& Kim, Y.K. (2015b). The impact of image congruence on brand attachment and loyalty: The moderating role of product type. The Journal of Advertising and Promotion Research, 4(1), 43-76. https://doi.org/10.14377/JAPR.2015.3.31.43

86. Kumar, N., Scheer, L.K., \& Steenkamp, J.B. (1995). The effects of supplier fairness on vulnerable resellers'. Journal of Marketing Research, 32(1), 54-65.

87. Kumar, R., Luthra, A., \& Datta, G. (2006). Linkages between brand personality and brand loyalty: A qualitative study in an emerging market in the Indian context. South Asian Journal of Management, 13(2), 1135.

88. Ladkin, A., \& Buhalis, D. (2016). Online and social media recruitment: Hospitality employer and prospective employee considerations. International Journal of Contemporary Hospitality Management, 28(2), 327-345. https://doi.org/10.1108/IJCHM-05-2014-0218

89. Le Roux, A., Chandon, J.L., \& Strazzieri, A. (1997). A confirmatory analysis of the PIA sustainable involvement measure. Proceedings of the 13th AFM International Congress, Toulouse, 958-986.

90. Lim, W. (2010). The effects of social media networks in the hospitality industry (Professional Papers). Retrieved June 26, 2012 from http://digitalscholarship.unlv.edu/thesesdissertations/693 
91. Lin, C.P. (2010). Modeling corporate citizenship, organizational trust, and work engagement based on attachment theory. Journal of Business Ethics, 94, 517-531. https://doi.org/10.1007/s10551-009-0279-6

92. Liu, Y., \& Shrum, L.J. (2002). What is interactivity and is it always such a good thing? Implications of definition, person, and situation for the influence of interactivity on advertising effectiveness. Journal of Advertising, 31(4), 53-64. https://doi.org/10.1080/00913367.2002.10673685

93. Lowry, P.B., Romano, N.C., Jenkins, J.L., \& Guthrie, R.W. (2009). The CMC interactivity model: How interactivity enhances communication quality and process satisfaction in lean-media groups. Journal of Management Information Systems, 26(1), 155-196. https://doi.org/10.2753/MIS0742-1222260107

94. 94. MacKenzie, S.B., Lutz, R.J., \& Belch, G. E. (1986). The role of attitude toward the Ad as an advertising effectiveness: A test of competing explanation. Journal of Marketing Research, 23(2), 130-143. https://doi.org/10.2307/3151660https://doi.org/10.1177/002224378602300205

95. Malik, M.E., Ghafor, M.M., \& Iqbal, H.K. (2013). Importance of brand awareness and brand loyalty in assessing purchase intentions of consumer. International Journal of Business and Social Science, 4(5), 167171.

96. Mandelli, A. (2008). Consumer involvement in organizations in the "organization as communication" perspective: A multidisciplinary research agenda. Observatorio Journal, 6, 111-119

97. Matos, C.A., \& Rossi, C.A. (2008). Word-of-mouth communications in marketing: A meta-analytic review of the antecedents and moderators. Journal of the Academy of Marketing Science, 36(4), 578-596. https://doi.org/10.1007/s11747-008-0121-1

98. McAllister, D.J. (1995). Affect- and cognition-based trust as foundations for interpersonal cooperation in organizations. Academy of Management Journal, 38(1), 24-59.

99. McMillan, S.J., \& Hwang, J.S. (2002). Measures of perceived interactivity: An exploration of the role of direction of communication, user control, and time in shaping perceptions of interactivity. Journal of Advertising Research, 31(3), 29-42. https://doi.org/10.1080/00913367.2002.10673674

100.Mollen, A., \& Wilson, H. (2010). Engagement, telepresence and interactivity in online consumer experience: Reconciling scholastic and managerial perspectives. Journal of Business Research, 63(9-10), 919-925. https://doi.org/10.1016/j.jbusres.2009.05.014

101. Montgomery, J.D. (1998). Toward a role-theoretic conception of embeddedness. American Journal of Sociology, 104(1), 92-125. https://doi.org/10.1086/210003

102.Morgan, R.M., \& Hunt, S.D. (2004). The commitment-trust theory of relationship marketing. Journal of Marketing, 58(3), 20-23.

103.Nadeem, W. (2016). Examining consumers' acceptance of social commerce in clothing e-retail (Unpublished doctoral dissertatin). University of Oulu, Finland.

104.Nadeem, W., Andreini, D., Salo, J., \& Laukkanen, T. (2015). Engaging consumers online through websites and social media: A gender study of Italian Generation Y clothing consumers. International Journal of Information Management, 35(4), 432-442. https://doi.org/10.1016/j.ijinfomgt.2015.04.008

105.Neirotti, P., Raguseo, E., \& Paolucci, E. (2016). Are customers' reviews creating value in the hospitality industry? Exploring the moderating effects of market positioning. International Journal of Information Management, 36(6)-Part A, 1133-1143. https://doi.org/10.1016/j.ijinfomgt.2016.02.010

106.Newhagen, J.E., Cordes, J.W., \& Levy, M.R. (1995). Nightly@nbc.com: Audience scope and the perception of interactivity in viewer mail on the internet. Journal of Communication, 45, 164-179. https://doi.org/10.1111/j.1460-2466.1995.tb00748.x

107.Nghia, H.T., Thanh, B.T., \& Bao, D.Q. (2017). The relationship between satisfaction, trust and repurchase intention: Examining the moderating role of word of mouth. Journal of Science Ho Chi Minh City Open University, 7(3), 111-124

108.Niyomsart, S., \& Khamwon, A. (2016). Brand love, brand loyalty and Word of mouth: A case of Air Asia. Journal of Arts \& Sciences, 9(1), 263-268.

109.Padilla-Meléndez, A., \& Garrido-Moreno, A. (2014). Customer relationship management in hotels: Examining critical success factors. Current Issues in Tourism, 17(5), 387-396. https://doi.org/10.1080/13683500.2013.805734

110.Park, W.C., MacInnis, D.J., Priester, J., Eisingerich, A.B., \& Iacobucci, D. (2010). Brand attachment and brand attitude strength: Conceptual and empirical differentiation of two critical brand equity drivers. Journal of Marketing, 74(6), 1-17. https://doi.org/10.1509/jmkg.74.6.1

111.Patterson, B.R., Bettini, L., \& Nussbaum, J.F. (1993).The meaning of friendship across the life-span: Two studies. Communication Quarterly, 41(2), 145-160.https://doi.org/10.1080/01463379309369875

112.Price, L.L., \& Arnould, E.J. (1999). Commercial friendships: Service provider-client relationships in context. Journal of Marketing, 63(4), 38-56. 
113.Rawlins, W.K. (1992). Friendship matters. Hawthome, NY: Aldine de Gruyter.

114.Richardson, P.S., Dick, A.S., \& Jain, A.K. (1994). Extrinsic and intrinsic cue effect on perceptions of store brand quality. Journal of Marketing Research, 58(4), 28-36. https://doi.org/10.1177/002224299405800403

115.Ridings, C.M., Gefen, D., \& Arinze, B. (2002). Some antecedents and effects of trust in virtual communities. Journal of Strategic Information Systems, 11(1), 271-295. https://doi.org/10.1016/S0963-8687(02)00021-5

116.Riegelsberger, J., Sasse, A.M., \& McCarthy, J.D. (2003). The researcher's dilemma: evaluating trust in computer-mediated communication. International Journal of Human-Computer Studies, 58(6), 759-781. https://doi.org/10.1016/S1071-5819(03)00042-9

117.Rosman, R., \& Stuhura, K. (2013). The implications of social media on customer relationship management and the hospitality industry. Journal of Management Policy \& Practice, 14(3), 18-26.

118.Schiffman, L.G., \& Kanuk, L.L. (2000). Consumer behavior. New York: Prentice Hall.

119.Schwartz, D., Dodge, K.A., Pettit, G.S., \& Bates, J.E. (2000). Friendship as a moderating factor in the pathway between early harsh home environment and later victimization in the peer group. Developmental Psychology, 36, 646-662. https://doi.org/10.1037/0012-1649.36.5.646

120.Selnes, F. (1998). Antecedents and consequences of trust and satisfaction in buyer-seller relationships. European Journal of Marketing, 32(3/4), 305-322. https://doi.org/10.1108/03090569810204580

121.Severin, W.J., \& Tankard, J.W. (2000). Communication theories: Origins, methods and uses in the mass media (5th Edition). New York: Addison Wesley Longman, Inc.

122.Shen, Y., Chi, C., \& Chen, J. (2007). A new perspective on the effects of price promotions in Taiwan: A longitudinal study of a Chinese society. International Journal of Consumer Studies, 31(4), 385-390 https://doi.org/10.1111/j.1470-6431.2006.00569.x

123.Sigala, M. (2005). Integrating customer relationship management in hotel operations: Managerial and operational implications. International Journal of Hospitality Management, 24, 391-413. https://doi.org/10.1016/j.ijhm.2004.08.008

124.Sigala, M., \& Chalkiti, K. (2015). Knowledge management, social media and employee creativity. International Journal of Hospitality Management, 45(1), 44-58. https://doi.org/10.1016/j.ijhm.2014.11.003

125.Sirohi, N., McLaughlin, E.W., \& Wittink, D.R. (1998). A model of consumer perceptions and store loyalty intentions for a supermarket retailer. Journal of Retailing, 74(2), 223-245. https://doi.org/10.1016/S0022$\underline{4359(99) 80094-3}$

126. Song, J.H., \& Zinkhan, G.M. (2008). Determinants of perceived web site interactivity. Journal of Marketing, 72(2), 99-113. https://doi.org/10.1509/jmkg.72.2.99

127.Stangl, B., Inversini, A., \& Schegg, R. (2016). Hotels' dependency on online intermediaries and their chosen distribution channel portfolios: Three country insights. International Journal of Hospitality Management, 52(1), 87-96. https://doi.org/10.1016/j.ijhm.2015.09.015

128.Steuer, J. (1992). Defining virtual reality: Dimensions determining telepresence. Journal of Communication, 42(4), 73-93. https://doi.org/10.1111/j.1460-2466.1992.tb00812.x

129.Stewart, D.W., \& Pavlou, P.A. (2002). From consumer response to active consumer: Measuring the effectiveness of interactive media. Journal of the Academy of Marketing Science, 30, 376-396. https://doi.org/10.1177/009207002236912

130.Su, N., Mariadoss, B.J., \& Reynold, D. (2015). Friendship on social networking sites: Improving relationships between hotel brands and consumers. International Journal of Hospitality Management, 51(1), 76-86. https://doi.org/10.1016/j.ijhm.2015.08.009

131.Sufi, T. (2008). Hospitality industry: An overview of strategy, structure and globalization. Journal of Hospitality Application \& Research, 3(1), 50-57.

132.Triplett, S.M., \& Loh, J.M.I. (2018). The moderating role of trust in the relationship between work locus of control and psychological safety in organisational work teams. Australian Journal of Psychology, 70(1), 76-84. https://doi.org/10.1111/ajpy.12168

133.Trusov, M., Bucklin, R.E., \& Pauwels, K. (2009). Effects of word-of-mouth versus traditional marketing: Findings from an internet social networking site. Journal of Marketing, 73(5), 90-102. https://doi.org/10.1509/jmkg.73.5.90

134.Urban, G.L., Sultan, F., \& Qualls, W.J. (2000). Placing trust at the center of your internet strategy. Sloan Management Review, 42(1), 39-49.

135.Van Doorn, J., Lemon, K., Mittal, V., Nass, S., Pick, D., Pirner, P., \& Verhoef, P. (2010). Customer engagement behavior: Theoretical foundations and research directions. Journal of Service Research, 13(3), 253-266. https://doi.org/10.1177/1094670510375599

136.Verhoef, P.C., \& Lemon, K.N. (2013). Successful customer value management: Key lessons and emerging trends. European Management Journal, 31(1), 1-15. https://doi.org/10.1016/j.emj.2012.08.001 
137. Vernuccio, M., Pagani, M., Barbarossa, C., \& Pastore, A. (2015). Antecedents of brand love in online networkbased communities: A social identity perspective. Journal of Product and Brand Management, 24(7), 706-719. https://doi.org/10.1108/JPBM-12-2014-0772

138. West, M., \& Dawson, J.F. (2012). Employee engagement and NHS performance. London: The Kings Fund.

139. Worthington, S., Russell-Bennett, R., \& Hartel, C.E.J. (2009). A tridimensional approach for auditing brand loyalty. Journal of Brand Management, 17(4), 243-253. https://doi.org/10.1057/bm.2009.24

140.Wu, G. (1999). Perceived interactivity and attitude towards website. In M.S. Roberts (Ed.). Proceedings of the 1999 Annual Conference of American Academy of Advertising. Gainesville, FL: University of Florida, 254262.

141.Wu, G. (2000). The role of perceived interactivity in interactive Ad processing (Unpublished doctoral dissertation). University of Texas at Austin, USA.

142.Yang, L., \& Mao, M. (2014, June). Antecedents of online group buying behavior: from price leverage and crowd effect perspectives. Proceedings of 2014 Pacific Conference on Information System (PACIS). Chengdu, China.

143. Yasin, M., \& Shamim, A. (2013). Brand love: Mediating role in purchase intentions and word-of-mouth. IOSR Journal of Business and Management, 7(2), 101-109. https://doi.org/10.9790/487X-072101109

144. Younus, S., Rasheed, F., \& Zia, A. (2015). Identifying the factors affecting customer purchase intention. Global Journal of Management and Business Research, 12(2), Version 1.0.

145. Yusuf, A.S. (2018). Influence of e-WOM engagement on consumer purchase intention in social commerce. Journal of Services Marketing, 32(4), 493-504. https://doi.org/10.1108/JSM-01-2017-0031

146.Zhao, H., Sullivan, K.P.H., \& Mellenius, I. (2014). Participation, interaction and social presence: An exploratory study of collaboration in online peer review groups. British Journal of Educational Technology, 45(5), 807-819. https://doi.org/10.1111/bjet.12094

147.Zhou, Z., Zhang, Q., Su, C., \& Zhou, N. (2012). How do brand communities generate brand relationships? Intermediate mechanisms. Journal of Business Research, 65(7), 890-895. https://doi.org/10.1016/j.jbusres.2011.06.034

148.Zhou, Z.M., Su, C.T., Zhou, N., \& Zhang, N. (2016). Becoming friends in online brand communities: Evidence from China. Journal of Computer-Mediated Communication, 21, 69-86. https://doi.org/10.1111/jcc4.12147 